\title{
Determinants of Micro and Small Scale Enterprises' financing preference in line with POH and Access to Credit: Empirical Evidence from Entrepreneurs in Ethiopia, Benishangul-Gumuz Regional State
}

Hayelom Abrha Meressa ( $\sim$ hayelommeresa@gmail.com )

Research

Keywords: Assosa Zone, Credit, Financing, logistic Regression, Micro and small enterprises

Posted Date: April 23rd, 2020

DOI: https://doi.org/10.21203/rs.3.rs-23092/v1

License: (c) (i) This work is licensed under a Creative Commons Attribution 4.0 International License. Read Full License 


\section{Abstract}

Purpose: The purpose of this study was to examine factors that determine micro and small scale enterprises' financing preference in line with pecking order theory and access to credit in Benishangul-Gumuz Regional State of Ethiopia.

Design / Methodology / Approach: The study used primary data collected using cross sectional survey questionnaire followed by mixed research approach. The sample of this study was 296 enterprises selected using proportional stratified random sampling technique. The data was analyzed using descriptive and logistic regression analysis.

Findings: The results of logistic regression analysis revealed that business experience, collateral, gender, motivation and enterprises' sectoral engagement affect financing preference of enterprises in line with pecking order hypothesis. On the second step, only enterprises that need to raise capital through credit were considered to investigate access to credit determinants. Accordingly, the logistic regression result revealed that business experience, size, sectoral engagement, collateral, interest rate, loan repayment period, financial reporting, preparation of business plan, location and educational background of entrepreneurs affect access to credit of enterprises.

Research limitations/Implications: More evidence is needed on enterprises' financing preference and access to credit determinants before any generalization of the results can be made. In addition, the empirical tests were conducted only on 296 entrepreneurs since 2019. Therefore, the results of the study cannot be assumed to extend beyond this group of entrepreneurs to different study periods.

Originality/value: This paper adds value to the literature on the determinants of micro and small scale enterprises' financing preference in line with pecking order hypothesis and access to credit.

\section{Introduction}

In spite of their contribution to employment, Micro and small scale enterprises (MSSEs, hereafter) face various constraints while operating their business (Haron, Said, Jayaraman, \& Ismail, 2013; Nguyen, Gan, \& Hu, 2015; Belanova, 2013; Ali, Godart, Gorg, \& Seric, 2016). Moreover, access to finance is by far the most critical bottleneck of MSSEs in Ethiopia (Assefa, Zerfu, \& Tekle, 2014; Menkir, 2016; Tarfasa, Ferede, Kebede, \& Behailu, 2016). In order to promote MSSEs as engines of growth, however, it is essential to understand the bottlenecks surrounding their access to finance (Mersha \& Ayenew, 2017). Otherwise, the financial constraints they face in their operations will daunt their development negatively that could limit their potential to drive the national economy as expected (Manaye \& Tigro, 2017).

In literature, there are various factors that may influence access to finance. Some argue that the fundamental reasons behind MSSEs' lack of access to funds can be found in their peculiar characteristics, while others argue that MSSEs suffer from financing gaps because of supply side factors (Mazanai \& Fatoki, 2012). Moreover, MSSEs may face financing gaps probably because of combination of factors originating from both the supply and demand sides (Stijn \& Tzioumis, 2006). However, irrespective of its source, whether raised internally by MSSEs owners or externally through credit, finance is needed to start and expand business. To identify literature based variables, systematic review was carried out on studies made by Alhassan \& Sakara, 2014; Awlachew \& Motumma, 2017; Elly \& Kaijage, 2017; Fufa, 2016; Gamage, 2013; Gebru, 2009; Haron, Said, Jayaraman, \& Ismail, 2013; Kebede, Tirfe, \& Abera, 2014; Kira \& He, 2012; Kung'u, 2011; Kuruppu \& Azeez, 2016; Makina, Fanta, Mutsonziwa, Khumalo, \& Maposa, 2015; Manaye \& Tigro, 2017; Marwa, Micro, 2014; Mashenene, 2015; Mersha \& Ayenew, 2017; Mole \& Namusonge, 2016; Nguyen \& Wolfe, 2016; Nega \& Hussein, 2016; Nguyen, Gan, \& Hu, 2015; Nkuah, Tanyeh, \& Gaeten, 2013; Osano \& Languitone, 2016; Waari \& Mwangi, 2015; Zarook, Rahman, \& Khanam, 2013)

With regard to financing MSSEs, the most competing theories of financing decisions are static trade-off theory and pecking order theory (Johnsen \& McMahon, 2005). On the one side, firm's optimal debt ratio is usually viewed as determined by a 
tradeoff of the costs and benefits of borrowing, holding the firm's assets and investment plans constant as of trade off theory. The firm is portrayed as balancing the value of interest tax shields against various costs of bankruptcy or financial embarrassment (Myers, 1984). On the other side, the pecking order model of corporate financing says that when a firm's internal cash flows are inadequate for its real investment, the firm issues debt (Shyam-Sunder \& Myers, 1999). However, an application of firm value optimization technique under static trade-off theory demands substantial reliable data. But, MSSEs usually have weakly organized accounting system (Gebru, 2009).

Therefore, the purpose of this study was to examine factors that determine micro and small scale enterprises' financing preference to establish whether these enterprises had followed the pecking order hypothesis and access to credit in their operation in Benishangul-Gumuz Regional State of Ethiopia using binary logistic regression. The remainder of this paper is structured as follows: Section two discusses about research methodology followed by section three that presents empirical results and discussion. Finally, section four provides the conclusion thereafter forwards recommendation.

\section{Research Methodology Research Design and Approach}

The research design was correlational explanatory research design based on a deterministic philosophy in which causes probably determine outcome followed by mixed approach.

\section{Data Type And Source}

The study used primary data collected from selected micro and small scale enterprises since 2019. The main instrument for data collection in this research was questionnaire which incorporated both open ended and close ended questions. The questionnaire was prepared in English language. Reliablity and validity of the instrument was also checked. It is evidenced in literature that reliability can be checked using test-retest measurements of the same construct administered to the same sample at two different points in time. Besides, validity can be assessed based on correlational coefficient of pilot test data in quantitative research (Bhattacherjee,2012). In this study, the survey instrument was first reviewed by lecturers of accounting and finance department in Assosa University for validity and then pre-tested to evaluate its suitability on 30 piloted entrepreneurs. Thereafter, a test-retest method was used to examine the reliability of the instrument and the instrument was administered twice to the same group of subjects at an interval of one month and gave a correlation coefficient of 0.724 that indicates high reliability of the instrument for the fact that coefficient of 0.5 and above is deemed reliable as of Kothari (2004).

\section{Population, Sample Size And Sampling Technique}

There were 1,140 micro and small scale enterprises according to the data obtained from Benishangul Gumuz Regional State of MSSEs agency during 2019. The target population of the study was, therefore, all micro and small business enterprises in the study area. Moreover, geographical and sectoral population distribution is given below in Table 1. 
Population Distribution

\begin{tabular}{|llllllllll|}
\hline Sector & \multicolumn{3}{l}{ Geographical location } & & & & & & $\begin{array}{c}\text { Sub } \\
\text { Total }\end{array}$ \\
\cline { 2 - 4 } & Assosa & Bambasi & Homosha & Menge & Sherkole & Kurmuk & Oda & $\begin{array}{c}\text { Mao- } \\
\text { komo }\end{array}$ \\
\hline Manufacturing & 49 & 6 & 5 & 1 & 3 & 0 & 0 & 1 & 65 \\
\hline Construction & 277 & 17 & 10 & 32 & 11 & 1 & 4 & 22 & 374 \\
\hline Service & 173 & 40 & 6 & 8 & 0 & 2 & 13 & 13 & 255 \\
\hline Agriculture & 136 & 31 & 18 & 46 & 8 & 13 & 19 & 4 & 275 \\
\hline Trade & 127 & 21 & 4 & 4 & 2 & 7 & 5 & 1 & 171 \\
\hline Total & 762 & 115 & 43 & 91 & 24 & 23 & 41 & 41 & 1140 \\
\hline Percentage & $67 \%$ & $10 \%$ & $4 \%$ & $8 \%$ & $2 \%$ & $2 \%$ & $3.5 \%$ & $3.5 \%$ & $100 \%$ \\
\hline
\end{tabular}

Indeed, sample size was determined based on the whole zonal active enterprises using a simplified formula which is developed by Yamane (1967).

$$
\begin{aligned}
& \text { Sample size }=\left(\frac{\text { population size }}{1+\text { population size }\left(\text { level of precision }{ }^{2}\right)}\right) \\
& \text { Samle size }=\left(\frac{1,140}{1+1,140\left(0.05^{2}\right)}\right)=296
\end{aligned}
$$

Where, level of precision $=5 \%$

Therefore, representative of 296 enterprises were used from the target enterprises. With regard to sampling technique of the survey, the study used a combination of cluster, stratified and purposive sampling methods. First, four clusters (Assosa Wereda, Bambasi Wereda, Menge Wereda, and Homosha Wereda) were selected purposely due to their relative higher enterprises' density. Thereafter, the enterprises were stratified in to manufacturing sector, construction sector, service sector, agricultural sector and trade to create sectoral homogeneity in each. Accordingly, proportional representative enterprises were selected through snowballing to come up with a total of 296 respondents as depicted in Table 2 below.

Table 2

\begin{tabular}{|c|c|c|c|c|c|c|c|c|c|c|}
\hline \multirow[t]{3}{*}{ Sector } & \multicolumn{8}{|c|}{ Geographical Location } & \multirow{2}{*}{\multicolumn{2}{|c|}{ Sub Total }} \\
\hline & \multicolumn{2}{|l|}{ Assosa } & \multicolumn{2}{|c|}{ Bambasi } & \multicolumn{2}{|c|}{ Homosha } & \multicolumn{2}{|l|}{ Menge } & & \\
\hline & Target & Sample & Target & Sample & Target & Sample & Target & Sample & Target & sample \\
\hline Manufacturing & 49 & 14 & 6 & 2 & 5 & 2 & 1 & 0 & 61 & 18 \\
\hline Construction & 277 & 81 & 17 & 5 & 10 & 3 & 32 & 9 & 336 & 98 \\
\hline Service & 173 & 51 & 40 & 12 & 6 & 2 & 8 & 2 & 227 & 67 \\
\hline Agriculture & 136 & 40 & 31 & 9 & 18 & 5 & 46 & 14 & 231 & 68 \\
\hline Trade & 127 & 37 & 21 & 6 & 4 & 1 & 4 & 1 & 156 & 45 \\
\hline Total & 762 & 223 & 115 & 34 & 43 & 13 & 91 & 26 & 1,011 & 296 \\
\hline
\end{tabular}

Proportional Distribution of Representatives 


\section{Variable Description And Model Specification}

The choice of dependent and independent variables with their measurement is a matter of no choice while specifying an empirical model. In line with this, dependent variables of this study were financing preference and access to credit by micro and small scale enterprises. Besides, independent variables were combination of owner's characteristics, firm related characteristics and creditor related variables which are described in Table 3.

Table 3

Nature and measurement of variables

\begin{tabular}{|c|c|c|c|c|}
\hline Variables & & Notation & Nature & Measurement \\
\hline \multirow[t]{2}{*}{ Dependent } & Financing preference & FINPRE & Categorical & $\begin{array}{l}1 \text { if enterprises raise fund internally } \& 0 \text { raise fund } \\
\text { externally through debt }\end{array}$ \\
\hline & Access to credit & ACCR & Categorical & $\begin{array}{l}1 \text { if enterprises have access to finance \& } 0 \\
\text { otherwise }\end{array}$ \\
\hline 1 & Collateral & COLAT & Categorical & 1 if there is collateral \& 0 otherwise \\
\hline 2 & Firm Size & SIZE & Categorical & Number of employees \\
\hline 3 & Location of MSSEs & LOC & Categorical & 1 = Assosa, 2 = Bambasi, 3 = Menge, $4=$ Homosha \\
\hline 4 & Business Experience & MAG & Continuous & Number of years in business \\
\hline 5 & Gender of owner & GOW & Categorical & taking value of 1 if male owned and 0 other wise \\
\hline 6 & Enterprise's sector & SECT & Categorical & $\begin{array}{l}\text { ( } 1 \text { = Manufacturing, } 2 \text { = Trade, } 3 \text { = Construction, } \\
4=\text { Service } \& 5=\text { Agriculture })\end{array}$ \\
\hline 7 & $\begin{array}{l}\text { Entrepreneurial } \\
\text { Interest }\end{array}$ & MOW & Categorical & $\begin{array}{l}1 \text { if owners join MSSE by choice } \& 0 \text { if it is by } \\
\text { lack of alternative }\end{array}$ \\
\hline 8 & Owner's education & OEDU & Categorical & $\begin{array}{l}(4=\text { No formal education, } 3=\text { elementary, } 2= \\
\text { secondary } 1=\text { vocational and university })\end{array}$ \\
\hline 9 & $\begin{array}{l}\text { Formal accounting } \\
\text { and reporting }\end{array}$ & RECFT & Categorical & $\begin{array}{l}1 \text { if there is record keeping of financial transactions } \\
\& 0 \text { otherwise }\end{array}$ \\
\hline 10 & Interest rate & IR & Categorical & 1 if low interest rate, otherwise 0 \\
\hline 11 & Lending procedures & LPR & Categorical & 1 if easy procedure, otherwise 0 \\
\hline 12 & Number of institutions & NINS & Categorical & 1 if many institutions \& 0 if few institutions \\
\hline 13 & $\begin{array}{l}\text { Loan repayment } \\
\text { period }\end{array}$ & LRP & Categorical & 1 if repayment period is high $\& 0$ if low duration \\
\hline
\end{tabular}

In this study binary logistic regression model was used to examine the relationship between independent variables and dependent variables (Financing preference and access to credit of MSSEs). The basis for selecting the binary logistic regression model was the nature of both the dependent variables which are financing preference and access to credit. The first dependent variable, financing preference, was rated and reported by the respondents with a discrete scale of 1 and 0 , where 1 is financing preference from internal sources and 0 is for financing preference from external sources. Access to credit was also rated and reported by the respondents with a discrete scale of 1 and 0 , where 1 is access to credit and 0 is for not accessing credit.

According to Gujarati (2004), the cumulative logistic probability distribution model for this study could be econometrically specified as follows: 


$$
P i=F(Z i)=\frac{1}{1+e^{-z i}}=\frac{1}{1+e^{-\left(\alpha+\sum \beta i X i\right)}}=\frac{e^{z}}{1+e^{z i}}
$$

Where ' $e$ ' is the base of natural logarithm; $P_{i}$ is the probability of success; $X_{i}$ represents the $i^{\text {th }}$ explanatory variables; $a$ \& $\beta_{i}$ are regression parameters to be estimated

If $\mathrm{P}_{\mathrm{i}}$, the probability of success, is given by Eq. 1 above, then $\left(1-\mathrm{p}_{\mathrm{i}}\right)$, probability of failure could therefore be:

$$
1-P i=\frac{1}{1+e^{Z i}}
$$

Thus, for ease of interpretation of the coefficients, a logistic model could be written in terms of the odds and log of odd by taking natural logarithm of Eq. 2. Indeed, we can rewrite the above equation as:

$$
\left(\frac{P i}{1-P i}\right)=\frac{1+e^{Z i}}{1+e^{-Z i}}=e^{Z i}
$$

Now, $\mathrm{Pi} /\left(1-\mathrm{P}_{\mathrm{i}}\right)$ is the odd ratio which is the ratio of the probability of success $\left(\mathrm{P}_{\mathrm{i}}\right)$ to the probability of failure. Now if we take the natural logarithm of Eq. 3, we could have the following result.

$$
Z i=\ln \left(\frac{P i}{1-p i}\right)=\alpha+\beta 1 X 1+\beta 2 X 2 \ldots \ldots \ldots+\beta m X m
$$

If the stochastic error term, $U_{i}$ is taken into account for estimation purpose, the logit model becomes:

The logistic regression can therefore be specified as:

$$
Z i=\alpha+\sum_{i=1}^{m} \beta i X i+U i
$$

$Y i=a+\beta 1 \times 1+\beta 2 \times 2+\ldots \ldots \beta X n+U i$

In this study, two dependent variables which are financing preference and access to credit were used. In both cases, MSSEs are assumed to have two choices which are "preference of internal financing" or "preference of debt financing" in the first scenario and MSSEs' "access credit" and "no access to credit" in the second case. Therefore, the binary choice logistic regression model that assumes dichotomous dependent variable which takes either 1 or 0 value was used. Accordingly, probability of success, $P_{i}$, represents probability of preferring internal source in the first case and probability of having access to credit for the second. On the other side, probability of failure, (1-Pi), represents probability of preferring external source in the first scenario and probability of not having access to credit for the second.

\section{Empirical Result And Discussion}

Both descriptive and logistic regression analysis were applied using STATA software version 13 for statistical treatment. In this section, descriptive statistics is carried out. 
Table 4

Financing preference of entrepreneurs

\begin{tabular}{|lll|}
\hline Financing Preference & Frequency & Percent \\
\hline External source & 162 & 54.73 \\
\hline Internal source & 134 & 45.27 \\
\hline Total & 296 & 100.00 \\
\hline
\end{tabular}

Source: Author's computation based on firm survey (2019)

Majority of the enterprises, almost $54.73 \%$ of the enterprises prefer to finance their businesses by external source of fund through credit. On the other side, $45.27 \%$ prefer to raise fund internally from their own source.

\begin{tabular}{|lll|}
\hline Sector & Frequency & Percent \\
\hline Agriculture & 18 & 6.08 \\
\hline Trade & 45 & 15.20 \\
\hline Construction & 98 & 33.11 \\
\hline Service & 67 & 22.64 \\
\hline Manufacturing & 68 & 22.97 \\
\hline Total & 296 & 100.00 \\
\hline
\end{tabular}

Table 5: Operational sectors of Enterprises

Source: Author's computation based on firm survey (2019)

In this study, five operational sectors were incorporated including enterprises engaged in trade, service, agricultural, construction and manufacturing sectors. Accordingly, the evidence indicates that $6.08 \%$ are engaged on agricultural sector, $15.2 \%$ are engaged on trade sector, $33.11 \%$ are engaged on construction, $22.64 \%$ are engaged on service sector, and the remaining $22.9 \%$ are engaged on Manufacturing sector.

Table 6

Business Experience of Enterprises

\begin{tabular}{|lll|}
\hline Business experience & Frequency & Percent \\
\hline $1-3$ years & 210 & 70.94 \\
\hline $4-5$ years & 79 & 26.69 \\
\hline Above 5 years & 7 & 2.37 \\
Total & 296 & 100.00 \\
\hline
\end{tabular}

Source: Author's computation based on firm survey (2019)

The survey revealed that majority of the respondents with $70.94 \%$ had operated their businesses for a period of fewer than three years followed by $26.69 \%$ with business experience that ranges between 4 and 5 years while those who had been in operation for more than five years shared the least percentage which is $2.37 \%$. Therefore, majority of the enterprises are at their start up stage. 
Table 7

Gender of respondents

\begin{tabular}{|lll|}
\hline Gender & Frequency & Percent \\
\hline Female & 120 & 40.54 \\
\hline Male & 176 & 59.46 \\
\hline Total & 296 & 100.00 \\
\hline Source: Author's computation based on firm survey (2019) \\
\hline
\end{tabular}

The results of the questionnaire indicated that $40.54 \%$ ) were female and the remaining $59.46 \%$ were male.

Table 8

Entrepreneurial interest of owners

\begin{tabular}{|lcc|}
\hline Motivation & Freq. & Percent \\
\hline Not Motivated & 170 & 57.43 \\
\hline Motivated & 126 & 42.57 \\
\hline Total & 296 & 100.00 \\
\hline Source: Author's computation based on firm survey (2019) \\
\hline
\end{tabular}

Among the enterprises, with regard to motivation of owners, almost $57.43 \%$ of the owners did not join to the sector by their choice and the rest $42.57 \%$ of the owners joined to their business with interest.

Table 9

Entrepreneurs' access to land

\begin{tabular}{|lll|}
\hline Land & Frequency & Percent \\
\hline Private owned & 164 & 55.41 \\
\hline Rented & 47 & 15.88 \\
\hline Government & 85 & 28.72 \\
\hline Total & 296 & 100.00 \\
\hline Source: Author's computation based on firm survey (2019) \\
\hline
\end{tabular}

Among the enterprises, majority of the respondents in the survey (55.41\%) use their own land for operation, $15.88 \%$ operated their businesses on rented houses while the remaining percentage (28.72\%) operate their business using premises from the government.

Table 10

Enterprises' access to finance

\begin{tabular}{|lll|}
\hline Access to Finance & Frequency & Percent \\
\hline Non participant & 60 & 37.04 \\
\hline Participant & 102 & 62.96 \\
\hline Total & 162 & 100.00 \\
\hline
\end{tabular}

Source: Author's computation based on firm survey (2019) 
The survey revealed that $62.96 \%$ of the respondents replied that their request for loan was accepted by lenders whereas $37.04 \%$ of the respondents reported rejection of their request.

Table 11

Sectoral Engagement of Enterprises with external source preference

\begin{tabular}{|lll|}
\hline Sector & Frequency & Percent \\
\hline Agriculture & 9 & 5.56 \\
\hline Trade & 28 & 17.28 \\
\hline Construction & 48 & 29.63 \\
\hline Service & 38 & 23.46 \\
\hline Manufacturing & 39 & 24.07 \\
\hline Total & 162 & 100.00 \\
\hline Source: Author's computation based on firm survey (2019) \\
\hline
\end{tabular}

The study revealed that among the enterprises that prefer external debt as means of financing, $5.56 \%$ are engaged on agricultural sector, $17.28 \%$ are engaged on trade sector, $29.63 \%$ are engaged on construction, $23.46 \%$ are engaged on service sector, and the remaining $24.04 \%$ are engaged on Manufacturing sector. Therefore, relatively, more of the enterprises engaged in construction sector Prefer external source of financing.

On the one side, according to the survey, $40.74 \%$ of owners of micro and small enterprises responded that they prepare business plan which could assist the operation of their businesses. On the other hand, $59.26 \%$ of the owners answered that they do not have business plan for their business and described that they faced number of problems one of which being lack of access to loan because business plan is a proposal that describes a business opportunity to financing. Among the enterprises that need to finance their operation from external sources through credit, $75.31 \%$ were operated in Assosa Wereda, $12.35 \%$ Bambasi Wereda, $8.02 \%$ in Menge and 4.32\% were operating in Oda.

\section{Econometric Analysis}

In this section regression analysis is carried out using odds ratio and marginal effect. In this study, the econometric analysis section consists of two step analysis. The first step is used to analyze financing preference of entrepreneurs to test pecking order theory of capital structure by binary logistic regression model. On the second step, only enterprises that need to raise capital through credit are considered. In this section discussion of financing preference determinants for micro and small scale enterprises is carried out. Prior to running logistic regression, explanatory variables were checked for the existence of multicollinearity problem by using Variance Inflation Factor (VIF). The study reveals that the VIF values are all well below 10 . Therefore, it can be safely conclude that there is no collinearity problem within the data.

The association between financing preference and its determinants was explained by using binary logistic regression model. In the logistic regression model, thus, the dependent variable, financing preference, was rated and reported by MSSEs' owners with a discrete scale of 0 and 1, where 1 indicates financing preference from internal sources like personal saving and retained earnings and 0 indicates preferring external sources. The Hosmer and Lemeshow test for the goodness of fit in the logistic model has Prob $>$ chi $2=0.8971$ which indicates that it is not statistically significant and therefore the model is quite a good fit. 
As indicated in Table 12, econometric results from binary logistic regression on financing preference of entrepreneurs' show that 5 of the 8 variables are highly influential on financing choice which includes business experience, collateral, gender, motivation and enterprises' sector. The other variables including firm size, education and access to land failed to show significant influence.

Table 12

Binary logistic regression output for determinants of financing choice for MSSEs

\begin{tabular}{|c|c|c|c|c|c|}
\hline Financing preference & Odds ratio & Robust Std. Error & $\mathbf{Z}$ & $P>|z|$ & $\mathrm{dy} / \mathrm{dx}$ \\
\hline Business Experience & 1.448879 & .1515305 & 3.55 & 0.000 & .091081 \\
\hline Size & 1.019316 & .0152382 & 1.28 & 0.201 & .0046996 \\
\hline Collateral & 3.885199 & 1.093248 & 4.82 & 0.000 & .3192377 \\
\hline Gender of owner & 2.787597 & .792821 & 3.60 & 0.000 & .2432498 \\
\hline Entrepreneurial Interest & 1.655454 & .4624081 & 1.80 & 0.071 & .123763 \\
\hline Agriculture & 1.220513 & .6996323 & 0.35 & 0.728 & .0493848 \\
\hline Trade & .4695177 & 2088995 & -1.70 & 0.089 & -.1747292 \\
\hline Construction & 1.331923 & .4934836 & 0.77 & 0.439 & .0707003 \\
\hline Service & .8045939 & .3119231 & -0.56 & 0.575 & -.0528945 \\
\hline \multicolumn{6}{|l|}{ Manufacturing } \\
\hline No formal Education & 1.357352 & 1.025741 & 0.40 & 0.686 & .0750903 \\
\hline Primary School & 2.122742 & 1.625447 & 0.98 & 0.326 & .1849294 \\
\hline Secondary School & .9409705 & .73583 & -0.08 & 0.938 & -.0149055 \\
\hline \multicolumn{6}{|l|}{ Vocational and above } \\
\hline Privately owned & 1.552812 & .4909606 & 1.39 & 0.164 & .1073382 \\
\hline Rent & .6924726 & .319417 & -0.80 & 0.426 & -.0882264 \\
\hline \multicolumn{6}{|l|}{ Government } \\
\hline Constant & .0277514 & .0271331 & -3.67 & 0.000 & \\
\hline \multicolumn{6}{|l|}{ Number of obs $=296$} \\
\hline \multicolumn{6}{|l|}{ Wald chi2 $(14)=56.00$} \\
\hline \multicolumn{6}{|l|}{ Prob $>$ chi $2=0.0000$} \\
\hline \multicolumn{6}{|c|}{ Log pseudo likelihood = -167.36886 } \\
\hline \multicolumn{6}{|l|}{ Pseudo R2 = 0.1789} \\
\hline \multicolumn{6}{|l|}{ number of groups $=10$} \\
\hline \multicolumn{6}{|c|}{ Hosmer-Lemeshow chi2(8) $=3.53$} \\
\hline Prob $>$ chi $2=0.8971$ & & & & & \\
\hline
\end{tabular}

Ceteris paribus, as described in Table 12 above, female owned micro and small scale enterprises was found to have positive relation with financing decision of MSSEs in light with pecking order theory and statistically significant at 1 percent. The odds ratio of the variable "gender of owner" indicates the probability of choosing internal financial source of 
MSSEs that are owned by female owners is 2.78 times higher than male owned counterparts. The marginal effect of this variable shows that the probability of choosing internal financing for female owned MSSEs increase by 24.32 percent as compared to male owned MSSEs. Therefore, it is evident that female owned MSSEs more likely prefer internal financial sources as compared to male owned MSSEs which is in favor of pecking order hypothesis of financing decision.

Entrepreneurial interest of micro and small scale enterprises' owners was found to have positive relation with financing decision of MSSEs following pecking order theory and statistically significant at 10 percent. The odds ratio of the variable indicates the probability of choosing internal financial source of MSSEs that are established by interested owners is 1.65 times higher than those who join to the business without interest due to lack of other choices. In addition, the marginal effect of this variable shows that the probability of choosing internal financing for motivated MSSEs' owners increase by 12. 37 percent as compared to their counterparts. Therefore, it is found that motivated entrepreneurs more likely prefer internal financial sources supporting pecking order hypothesis. This result contradicts with the finding of a study made by Gebru (2009) in MSSEs of Tigray regional state that revealed voluntary entrants have better entrepreneurial orientation than their forced entrant counterparts for the fact that the MSE owners who voluntarily started business have a relatively good deal of entrepreneurship behavior and relatively higher preference for external financing scheme.

Sectoral engagement of micro and small scale enterprises was found to have negative relation with financing decision of MSSEs' owners and statistically significant at 10 percent. The odds ratio of the variable indicates the probability of choosing internal financial source of MSSEs that are engaged in trade sector is .46 times lower than those who are engaged in manufacturing sector. The marginal effect of this variable shows that the probability of choosing internal financing for MSSEs' owners engaged in service sector decrease by 17. 47 percent as compared to those engaged in manufacturing sector.

Ceteris paribus, collateral of micro and small scale enterprises was found to have positive relation with financing decision of MSSEs owners and statistically significant at 1 percent in light of pecking order hypothesis. The odds ratio of the variable indicates the probability of choosing internal financial source of MSSEs who have collateral is 3.88 times higher than their counter parts. The marginal effect of this variable shows that the probability of choosing internal financing for MSSEs' owners who have collateral increase by 31.92 percent as compared to their counterparts in light of pecking order theory of financing decision.

Business experience, measured by year of establishment, has a positive effect on financing decision at 1 percent significant level statistically in favor of pecking order theory of financing decision. The odds ratio in favor of internal financing is increased by 1.44 times as the business experience increases by one year. In addition, the marginal effect implies that, ceteris paribus, the probability of choosing internal financial source increases by 9 percent as business experience increases by a year.

In the following logistic regression result, only those enterprises with external financing preference were considered. Therefore, 'access to credit' refers to those respondents who were able to receive credit from a lending institution, taking a dichotomous response variable of 'yes indicated by 1' or 'no indicated by 0 ' for those who had credit and those who did not respectively. 
Table 13

Binary Logistic Regression Output for Determinants of MSSEs' access to credit

\begin{tabular}{|c|c|c|c|c|c|}
\hline Access to Finance & Odds Ratio & $\begin{array}{l}\text { Robust } \\
\text { Std. Err. }\end{array}$ & $\mathbf{Z}$ & $P>|z|$ & $d y / d x$ \\
\hline Business Experience & 25.02736 & 17.47958 & 4.61 & 0.000 & .3360495 \\
\hline Size & 1.118705 & .0511221 & 2.45 & 0.014 & .0117067 \\
\hline Agriculture & 1.743648 & 1.806012 & 0.54 & 0.591 & .0480608 \\
\hline Trade & 2.485743 & 3.170472 & 0.71 & 0.475 & .0763496 \\
\hline Construction & .4126838 & .378931 & -0.96 & 0.335 & -.1065709 \\
\hline Service & 16.95304 & 24.20197 & 1.98 & 0.047 & .1917092 \\
\hline Manufacturing & Reference & & & & \\
\hline Collateral & 30.81225 & 30.63382 & 3.45 & 0.001 & .3344499 \\
\hline Interest rate & .1365352 & .1174511 & -2.31 & 0.021 & -.2119259 \\
\hline Loan repayment period & .1318583 & .1586324 & -1.68 & 0.092 & -.145497 \\
\hline Gender & 2.199182 & 2.170373 & 0.80 & 0.425 & .0836379 \\
\hline Financial Reporting & 29.81018 & 35.44641 & 2.86 & 0.004 & .2641792 \\
\hline Lending procedure & 2.215662 & 2.202821 & 0.80 & 0.424 & .0984125 \\
\hline Formal Registration & 1.952885 & 1.763223 & 0.74 & 0.459 & .0664577 \\
\hline Business Plan & 35.49375 & 32.35682 & 3.92 & 0.000 & .3490687 \\
\hline Assosa & .8057219 & 1.024949 & -0.17 & 0.865 & -.0216332 \\
\hline Bambasi & 23.93971 & 35.68499 & 2.13 & 0.033 & .1575461 \\
\hline Menge & 4.080869 & 7.827546 & 0.73 & 0.463 & .0951464 \\
\hline Homosha & Reference & & & & \\
\hline No formal Education & .0259615 & .0433449 & -2.19 & 0.029 & -.3724623 \\
\hline Primary School & .0034252 & .0053947 & -3.60 & 0.000 & -.8863744 \\
\hline Secondary School & .0109665 & .0192112 & -2.58 & 0.010 & -.7791879 \\
\hline Vocational and above & Reference & & & & \\
\hline Number of institutions & .5051351 & .4534486 & -0.76 & 0.447 & -.0812596 \\
\hline Constant & .0007358 & .0019307 & -2.75 & 0.006 & \\
\hline
\end{tabular}




\begin{tabular}{|ll|}
\hline Access to Finance $\quad$ Odds Ratio & $\begin{array}{l}\text { Robust } \\
\text { Std. Err. }\end{array}$ \\
\hline Number of obs $=162$ & \\
Wald chi2(21) $=53.59$ & \\
Prob $>$ chi2 $=0.0001$ & \\
Log pseudo likelihood $=-27.890359$ & \\
Pseudo R2 $=0.7388$ \\
number of groups $=10$ \\
Hosmer-Lemeshow chi2(8) $=0.85$ \\
Prob $>$ chi2 $=0.9990$
\end{tabular}

As indicated in Table 13 above, the Hosmer and Lemeshow test for the goodness of fit in the logistic model has Prob > chi2 $=0.9990$ which indicates that it is not statistically significant and therefore the model is quite a good fit. Business experience has a positive effect on access to credit at 1percent significant level statistically. The odds ratio in favor of access to credit is increased by 25.02 times as the business experience increases by one year. In addition, the marginal effect implies that, ceteris paribus, the probability of accessing credit increases by 33.6 percent as business experience increases by a year.

Enterprise size has a positive and statistically significant effect on MSSEs' access to credit at $1 \%$ level of significance. Holding other factors constant, the odds ratio in favor of access to credit is increased by 1.11 times as the number of employee's increases by one. The marginal effect shows that the probability of accessing credit increases by 11.1 percent for MSSEs as employee number by a unit.

The logistic regression results indicates that holding other factors constant, the probability of accessing credit for MSSEs that are engaged in service sector is 16.95 times higher than those engaged in manufacturing sector at 5 percent significance level statistically. The marginal effect shows that the probability of accessing credit increases by 19.17 percent for those MSSEs that are engaged in service sector than those engaged in manufacturing sector.

The output of binary regression revealed that the variable collateral, represented by possession of fixed asset, has a positive and statistically significant effect on MSSEs' access to credit at $1 \%$ level of significance level statistically. The odds ratio indicates that MSSEs which have fixed asset are 30.81 times more likely to access credit than their counter parts. The marginal effect, in addition, shows that the probability of accessing credit increases by 33.44 percent for those MSSEs that have collateral than their counter parts.

Interest rate has a negative and statistically significant association with MSSEs 'access to credit at $5 \%$ significance level statistically. The odds ratio indicates that MSSEs with negative attitude about interest rate are 0.13 times less likely access credit than their counter parts. The marginal effect, in addition, shows that the probability of accessing credit decreases by 21.19 percent for those MSSEs' owners who believe that interest rate of loan is higher than their counter parts.

Loan repayment period has a negative and statistically significant association with MSSEs 'access to credit at $10 \%$ significance level statistically. The odds ratio indicates that MSSEs with negative attitude about loan repayment period are 0.13 times less likely access credit than their counter parts. This is to mean that opinion about loan repayment period does not affect the probability of MSSEs owners' access to credit. 
The output of binary regression revealed that financial reporting has a positive and statistically significant effect on MSSEs access to credit at $1 \%$ level of significance statistically. The odds ratio indicates that MSSEs that prepare financial reporting are 29.81 times more likely to access credit than their counter parts. The marginal effect, in addition, shows that the probability of accessing credit increases by 26.41 percent for those MSSEs that prepare financial reporting than their counter parts.

The odds ratio shows that the probability of MSSEs' access to credit with business plan is 35.49 times higher than their counter parts. The marginal effect also indicated that the probability of MSSEs' access to credit with business plan increased by $34.9 \%$ compared to MSSEs that don't have business plan at 1 percent level of significance statistically.

Location of enterprises has a positive and significant influence on MSSEs' access to finance. The odds ratio indicates that, holding other factors constant, probability of access to finance for MSSEs operate at Bambasi Wereda is 23.93 times higher than those operated in Assosa Wereda.

Educational level of the MSSEs' owner/manager has a positive and statistically significant effect on MSSEs' access to credit at $5 \%$ level of significance statistically. The odds ratio indicates that MSSEs who have not formal education are 0.026 times less likely to access credit compared with those who attend TVET and above. The odds ratio for primary school education is 0.003 . This indicates that compared to MSSE owners/ mangers who have attended TVET and above, those with who attend primary school are 0.003 times less likely to get credit at $1 \%$ level of significance statistically. In the same vein, the odds ratio indicates that MSSEs who attend education in secondary school are 0.01 times less likely to access credit compared with those who attend TVET and above.

\section{Conclusion And Recommendation}

The purpose of this study was to examine factors that determine micro and small scale enterprises' financing preference in line with pecking order theory and access to credit in their operation in Benishangul-Gumuz Regional State of Ethiopia using logistic regression using two stage analysis.

The first step is used to analyze financing preference of entrepreneurs and its determinants to test whether the firms followed pecking order hypothesis in their financing decision by binary logistic regression model using data collected from 296 enterprises. The evidence revealed that almost $54.73 \%$ (162) of the enterprises prefer to finance their businesses by external source of fund through credit. On the other side, $45.27 \%$ (134) prefer to raise fund internally from their own source. Therefore, majority of the entrepreneurs did not follow a financing decision suggested by pecking order hypothesis. The results of logistic regression analysis revealed that business experience, collateral, gender, motivation and enterprises' sectoral engagement affect financing preference of enterprises. On the second step, only enterprises that need to raise capital through credit (162 enterprises) were considered to investigate the determinants of access to credit. Accordingly, the survey revealed that $62.96 \%$ (102) of the respondents replied that their request for loan was accepted by lenders whereas $37.04 \%$ (60) of the respondents reported rejection of their request. The logistic regression result revealed that business experience, size, sectoral engagement, collateral, interest rate, loan repayment period, financial reporting, preparation of business plan, location and educational status of entrepreneurs affect access to credit of enterprises. Therefore, it is recommended that MSSEs' owners should share business experience, improve entrepreneurial interest, prepare business plan and produce financial report for the fact that these variables are powerful in explaining outcomes of the study.

\section{Abbreviations}

MSSEs: Micro and Small Scale Enterprises; MFIs: Micro Finance Institutions; POH: Pecking order hypothesis; TVET: Technical and Vocational Education and Training

Page $14 / 21$ 


\section{Declarations}

\section{Availability of data and materials}

The data that support the findings of the study can be obtained from the author based on request.

\section{Competing interests}

The author declare that there is no competing interest

\section{Funding}

This research was sponsored by Assosa University.

\section{Author's contributions}

The author personally undertook this research paper. The author also read and approved the final manuscript.

\section{Ethics approval and consent to participate}

'Not applicable'

\section{Acknowledgements}

'Not applicable'

\section{Authors' information}

'Not applicable'

\section{Consent for publication}

The author personally approve that the paper should be published in your journal.

\section{References}

Abara, G., \& Banti, T. (2017). Role of Financial Institutions in the Growth of Micro and Small Enterprises in Assosa Zone. Research Journal of Finance and Accounting, Vol.8(No.3), PP.36-40.

Abay, H. H., Tessema, F. G., \& Gebreegziabher, A. H. (2014). External Factors Affecting the Growth of Micro and Small Enterprises (MSEs) in Ethiopia:A Case Study in Shire Indasselassie Town, Tigray. European Journal of Business and Management, Vol.6(No.34), PP.134-145.

Abdul-Rahamon, O. A., \& Adejare, A. T. (2014). The Analysis of the impact of Accounting Records Keeping on the Performance of the Small Scale Enterprises. International Journal of Academic Research in Business and Social Sciences, Vol.4(No.1), PP.1-17.

Abebe, A., Robe, M., \& Maru, M. (2016). Assessment On Challenges and Performances of Micro and Small Enterprises in Benishangul Gumuz Regional State: Formalization is the way Forward. Research for Community and Self not for Shelf. Assosa University.

Adem, M., Worku, H., \& Beyene, D. (2014). Constraints and Growth Potentials of Micro and Small Enterprises: Case from Mekelle City. International Journal of Scientific and Research Publications, Vol.4(No.12), PP.1-7. 
Afrasiabishani, J., Ahmadinia, H., \& Hesami, E. (2012). A Comprehensive Review on Capital Structure Theories. School of Doctoral Studies (European Union) Journal.

Agyapong, D. (2010). Micro, Small and Medium Enterprises' Activities, Income Level and Poverty Reduction in Ghana - A Synthesis of Related Literature. International Journal of Business and Management, Vol.5(No.2), PP.196-205.

Agyapong, D., \& Appiah, S. O. (2015). Effect of Gender Diversity on the Performance of Non-financial Listed Firms in Ghana. British Journal of Economics, Management \& Trade, Vol.8(No.1), PP.55-67.

Ahiawodzi, A. K. (2012). Access to Credit and Growth of Small and Medium Scale Enterprises in the Ho Municipality of Ghana. British Journal of Economics, Finance and Management Sciences, Vol.6(No.2), PP.34-51.

Ahmad, M., Ahmad, E., Kahut, M. B., \& Murtaza, G. (2012). New Determination Of Factors Affecting The Growth Of Small And Medium Sized Enterprises In Pakistan. Interdisciplinary Journal Of Contemporary Research In Business, Vol.4(No.6), PP.513-530.

Alemayehu, D., \& Gecho, Y. (2016). Determinants of Micro and Small Enterprises Growth:The Case of Durame Town, Kembata Tembaro Zone,Southern Nations and Nationalities and Peoples Region,Ethiopia. International Journal of Business and Economics Research, Vol.5(No.5), PP.161-175.

Alemu, K. S. (2015). Business Characteristics as a Determinant of MSE Growth. International Journal of Novel Research in Marketing Management and Economics, Vol.2(No.2), PP.8-24.

Alhassan, F., \& Sakara, A. (2014). Socio-Economic Determinants of Small and Medium Enterprises' (Smes) Access to Credit from the Barclays Bank in Tamale-Ghana. International Journal of Humanities \& Social Science Studies, Vol. 1(No.2), PP.2636.

Ali, M., Godart, O., Gorg, H., \& Seric, A. (2016). Cluster Development Programs in Ethiopia:Evidence and Policy Implications. United Nations Industrial Development Organization (UNIDO).

Amene, T. B. (2017). Factors Affecting Access To Finance For Micro And Small Enterprises: The Case Of West Hararghe Zone, Ethiopia. International Journal of Current Research, Vol.9(No.11), pp.61886-61893.

Assefa, B., Zerfu, A., \& Tekle, B. (2014). Identifying Key Success Factors And Constraints In Ethiopia's MSE Development: An Exploratory Research. Ethiopian Development Research Institute.

Attom, B. E. (2013). Cash Management Practices By Micro And Small-Scale Enterprises At Kasoa In The Central Region Of Ghana. Asian Journal of Business and Management Sciences, Vol.3(No.2), PP.1-12.

Awlachew, T. D., \& Motumma, A. D. (2017). Determinants of Financing Preferences of Micro and Small Enterprises Owners: In Case of Dire Dawa City Administration of Ethiopia. Research Journal of Finance and Accounting, Vol.8(No.3), PP.21-27.

Aynadis, Z., \& Mohammednur, M. (2014). Determinants of Growth of Micro and Small Enterprises in ETHIOPIA (A Case of MSEs in Mekelle City, Tigray). International Journal of Advance Research in Computer Science and Management Studies, Vol.2(No.6), PP.149-157.

Beck, T. (2007). Financing Constraints of SMEs in Developing Countries: Evidence, Determinants and Solutions. Financing Innovation-Oriented Businesses to Promote Entrepreneurship.

Bhattacherjee, A. (2012). Social Science Research: Principles, Methods, And Practices (Second Edition ed.). 
Borji, B., \& Gashu, M. (2015). Factors Affecting Access To Finance With Reference To Micro And Small Enterprise In Dilla Town, Ethiopia. Vol.4(No.2), PP.1680-1687.

Bouazza, A. B., Ardjouman, D., \& Abada, O. (2015). Establishing the Factors Affecting the Growth of Small and Mediumsized Enterprises in Algeria. American International Journal of Social Science, Vol.4(No.2), PP.101-115.

Brooks, C. (2014). Introductory Econometrics for Finance (3rd edition ed.). Cambridge University Press, New York.

Brown, J. D. (2002). Th e $\mathrm{C}$ ron b ach alp h a reliab ilit y es $\mathrm{t}$ im at e. JALT Testing \& Evaluation SIG Newsletter, Vol.6(No.1), PP.17-18.

Drbie, M., \& Kassahun, T. (2013). Deterrents to the Success of Micro and Small Enterprises in Akaki-Kality Sub-City. JBAS, Vol.5(No.2), PP.1-34.

Elly, D., \& Kaijage, E. S. (2017). Effects of Demand Side Factors on Access to External Finance by Small and Medium Manufacturing Enterprises in Nairobi, Kenya . African development finance journal, Vol.11(No.1), PP 44-60.

Emana, B. (2010). Market Assessment and Value Chain Analysis in Benishangul Gumuz Regional State, Ethiopia.

Emmanuel, A. T., Dele, A. O., \& Odunlami, I. B. (2013). Determinants of Small and Medium Enterprises (SMEs) Performance in Ekiti State, Nigeria: A Business Survey Approach. European Journal of Humanities and Social Sciences, Vol.27(No.1).

Engida, E., Dereje, M., Worku, I., Yimer, F., \& Yifredew, S. (2017). The major bottlenecks of micro and small scale enterprises' growth in Ethiopia: An econometric analysis. Policy analysis on Growth and Employment, Working Paper 2017-19.

Esubalew, A. A., \& Raghurama, A. (2017). Micro, Small and Medium Enterprises(MSMEs)Development Strategies in Ethiopia: Retrospective and Prospective Analysis. International Journal of Commerce, Business and Management, Vol.6(No.1), PP.11-20.

Fanta, A. B. (2015). Demand Side Constraints To Sme Access To External Finance: Evidence From Survey Of Manufacturing Firms In Ethiopia. Journal of Accounting and Management, PP.1-15.

Farouk, A., \& Saleh, M. (2011). An Explanatory Framework for the Growth of Small and Medium Enterprises. International Conference of System Dynamics Society.

FELEKE, D. (2015). Factors Affect The Growth Of Micro And Small Enterprises In Hossana Town, SNNPR.

Fissiha, Y. (2016). Determinants of the Growth of MSEs in Ethiopia:The Case Study of Bahir Dar City Administration. The International Journal Of Business \& Management, Vol.(No.7), PP.75-96.

Fufa, F. G. (2016). Determinants of Access to Credit and Credit Source Choice by Micro, Small and Medium Enterprises in Nekemte, Ethiopia. International Journal of African and Asian Studies, Vol.28.

Gamage, P. (2013). Determinants Of Access To Bank Finance For Small And Medium-Sized Enterprises: The Case Of Sri Lanka . CO Rp O Ra Te O W N Ersh Ip \& CON Tro L, Vol.1O(No.3).

Gawali, R. B., \& Gadekar, A. (2017). Financial Management Practices in Micro, Small and Medium Enterprises-An Exploratory Analysis with the help of Literature Review. International Journal of Research in Finance and Marketing, Vol.7(No.6), pp. 45-59.

Gebreeyesus, M. (2007). Growth of Micro-Enterprises: Empirical evidence from Ethiopia. Ethiopian Development Research Institute (EDRI). 
Gebremichael, B. A. (2014). The Impact of Subsidy on the Growth of Small and Medium Enterprises (SMEs). Journal of Economics and Sustainable Development, Vol.5(No.3), PP.178-188.

Gebru, G. H. (2009). Financing preferences of micro and small enterprise owners in Tigray: does POH hold? Journal of Small Business and Enterprise Development, Vol.16(No.2), pp. 322-334.

Gebru, G. H. (n.d.). Research Methods and Analysis for Business Studies: a holistic approach . College of Business and Economics ,Mekelle University, Mekelle,Ethiopia .

Getahun, M. (2016). The Challenge and Prospects of Small Scale Enterprise in Ethiopia: A Survey of Some Selected Small Scale Enterprise in Addis Ababa City. International Journal of Scientific and Research Publications, Vol.6(No.5), PP.614626.

Govori, A. (2013). Factors Affecting the Growth and Development of SMEs: Experiences from Kosovo. Mediterranean Journal of Social Sciences, Vol.4(No.9), PP.701-708.

Haron, H., Said, S. B., Jayaraman, K., \& Ismail, I. (2013). Factors Influencing Small Medium Enterprises (SMES) in Obtaining Loan. International Journal of Business and Social Science, Vol.4(No.5), PP.182-195.

Haron, H., Said, S. B., Jayaraman, K., \& Ismail, I. (2013). Factors Influencing Small Medium Enterprises (SMES) in Obtaining Loan. International Journal of Business and Social Science, Vol.4(No.15), PP.182-195.

Hassan, T., \& Ahmad, B. (2016). The Role of Micro Enterprises in Employment and Income Generation: A Case Study of Timergara City Dir (L) Pakistan. International Journal of Economics \& Management Sciences, Vol.5(No.2).

Javali, S. B. (2011). Effect of Varying Sample Size in Estimation of Coefficients of Internal Consistency. WebmedCentral BIOSTATISTICS, Vol.2(No.2).

Jennifer, K., \& Dennis, O. (2015). inancial Management Practices on growth of Small and Medium Enterprises: A case of Manufacturing Enterprises in Nairobi County, Kenya. IOSR Journal of Business and Management, Vol.17(No.8), PP. 65-77.

Johnsen, P. C., \& McMahon, R. G. (2005). Cross-industry differences in SME financing behaviour An Australian perspective. Journal of Small Business and Enterprise Development, Vol.12(No.2), pp. 160-177.

Kahando, D. M., Maina, T. M., \& Maina, C. M. (2017). An Appraisal of Financial Management Practices on the Growth of Micro Enterprise in Kenya . Journal of Business and Economic Development, Vol.2(No.1), PP. 63-70.

Kamunge, M. S., Njeru, A., \& Tirimba, O. I. (2014). Factors Affecting the Performance of Small and Micro Enterprises in Limuru Town Market of Kiambu County,Kenya. International Journal of Scientific and Research Publications, Vol.4(No.12), PP.1-20.

Kebede, S. N., Tirfe, A. G., \& Abera, N. (2014). Determinants of Micro and Small Enterprises' Access to Finance. Developing Country Studies, Vol.4(No.21), PP.90.

Kira, A. R. (2013). Determinants of Financing Constraints in East African Countries' SMEs. International Journal of Business and Management, Vol.8(No.8), PP.49-68.

Kira, A. R., \& He, Z. (2012). The Impact of Firm Characteristics in Access of Financing by Small and Medium-sized Enterprises in Tanzania. International Journal of Business and Management, Vol.7(No.24).

Kung'u, G. K. (2011). Factors Influencing Small and Medium Enterprises' Access to Funding in Kenya: A Case Study of Westlands Division. Munich Personal RePEc Archive.

Page 18/21 
Kuruppu, G., \& Azeez, A. (2016). Financing Preferences of Small and Medium Enterprise Owners of Sri Lanka: Does Pecking Order Theory Hold? Journal of Business \& Economic Policy, Vol.3(No.2).

Lakew, D. M., \& Birbirsa, Z. A. (2017). Accounting and Reporting Practice of Micro and Small Enterprises in West Oromia Region. Research Journal of Finance and Accounting, Vol.8(No.9).

Leza, T., Rajan, S., \& Kuma, B. (2016). Determinants Of Employment Growth Of Micro And Small Enterprises In Wolaita Zone, Ethiopia;. International Journal of Current Research, Vol.8(No.12), pp.43177-43186.

Loewe, M., Al-Ayouty, I., Altpeter, A., Borbein, L., Chantelauze, M., Kern, M., . . Reda, M. (2013). Which Factors Determine the Upgrading of Small and Medium-Sized Enterprises (SMEs)? The case of Egypt. German Development Institute in cooperation with the Egyptian Center for Economic Studies (ECES).

Makina, D., Fanta, A. B., Mutsonziwa, K., Khumalo, J., \& Maposa, O. (2015). Financial Access and SME Size in South Africa. Manaye, M. K., \& Tigro, M. G. (2017). Challenges for Small and Micro Enterprises in Accessing Finance (Case of Wolaita Soddo Town). Global Journal of Management and Business Research, Vol.17(No.7).

Marwa, N. (2014). Micro, Small and Medium Enterprises' External Financing Challenges: The Role of Formal Financial Institutions and Development Finance Intervention in Tanzania. International Journal of Trade, Economics and Finance, Vol.5(No.3), PP.230-234.

Mashenene, R. G. (2015). Constraints of Accessing Debt Financing from Commercial Banks among Small and Medium Enterprises in Tanzania: A Literature Review. Proceedings of the Second European Academic Research Conference on Global Business, Economics, Finance and Banking.

Mazanai, M., \& Fatoki, O. (2012). Access to Finance in the SME Sector: A South African Perspective. Asian Journal of Business Management, Vol.4(No.1), PP.58-67.

Mbugua, J. K., Mbugua, S. N., Wangoi, M., Ogada, J. O., \& Kariuki, J. N. (2013). Factors Affecting the Growth of Micro and Small Enterprises: A Case of Tailoring and Dressmaking Enterprises in Eldoret. International Journal of Business and Social Science, Vol.4(No.15), PP.285-293.

Menkir, F. G. (2016). Access to Finance and its Challenges for Private Sector in Ethiopia. Indira Gandhi National Open University School of social science.

Mersha, D., \& Ayenew, Z. (2017). Determinants of Access to Formal Financial Sources of Micro and Small Enterprises (MSEs) in West Oromia Region, Ethiopia . International Journal of Business and Economics Research, Vol.6(No.5), PP.100110.

Mole, S. A., \& Namusonge, G. (2016). Factors Affecting Access to Credit By Small and Medium Enterprises: A Case of Kitale Town. The International Journal of Social Sciences and Humanities Invention, Vol.3(No.10), PP.2904-2917.

Mutua, O. M. (2015). Effect Of Bookkeeping On The Growth Of Small And Medium Enterprises In Chuka Town. European Journal of Business and Social Sciences, Vol.4(No.7), PP. 102 - 112.

Nakagawa, Y. (2015). The Gender Diversity -Firm Performance Relationship By Industry Type, Working Hours, And Inclusiveness:An Empirical Study Of Japanese Firms. Journal of Diversity Management, Vol.10(No.1), PP.61-78.

Nathan, O. F., Molefhe, L., Mupimpila, C., Nkuba, M., \& Okurut, M. L. (2015). Determinants Of Sme Growth In Botswana. IDR, Vol.13(No.1), PP.51-70. 
Nega, F., \& Hussein, E. (2016). Small and Medium Enterprise Access to Finance in Ethiopia: Synthesis of Demand and Supply. The Horn Economic and Social Policy Institute.

Nganda, J. W., Wanyonyi, K. W., \& Kitili, E. M. (2014). Determinants of growth of small and medium enterprises in Kakamega central sub-county, Kenya. Journal of Business Administration and Management Sciences Research, Vol.3(No.3), pp. 022-031.

Nguyen, \& Wolfe. (2016). Determinants of Successful Access to Bank Loans by Vietnamese SMEs: New Evidence from the Red River Delta. Journal of Internet Banking and Commerce, Vol.21(No.1), PP.1-23.

Nguyen, N., Gan, C., \& Hu, B. (2015). An empirical analysis of credit accessibilty of small and medium sized enterprises in Vietnam. Banks and Bank Systems, Vol.10(No.1), PP.34-46.

Nkuah, J. K., Tanyeh, J. P., \& Gaeten, K. (2013). Financing Small And Medium Enterprises (Smes) In Ghana: Challenges And Determinants In Accessing Bank Credit. International Journal of Research In Social Sciences, Vol.2(No.3), PP.12-25.

Ntim, A. L., Evans, O., \& Anthony, F. (2014). Accounting practices and control systems of small and medium size entities: A case study of Techiman municipality. Journal of Finance and Accounting(Vol.2), PP.30-40.

Nuriye, G., \& S.S.A.Jafri. (2014). Policy Direction and Performance Evaluation of Micro and Small Enterprises in Southern Nations, Nationalities and People's (SNNP) State of Ethiopia . Developing Country Studies, Vol.4(No.7), PP.30-38.

Nyang'au, S. P. (2014). The Influence of Entrepreneurship on the Growth of Micro and Small Enterprises in Thika Town, Kenya. International Journal of Business, Humanities and Technology, Vol.4(No.2), PP.82-87.

Oppong, M., Owiredu, A., \& Churchill, R. Q. (2014). Micro And Small Scale Enterprises Development In Ghan. European Journal of Accounting Auditing and Finance Research, Vol.2(No.6), pp. 84-97.

Osano, H. M., \& Languitone, H. (2016). Factors influencing access to finance by SMEs in Mozambique: case of SMEs in Maputo central business district. Journal of Innovation and Entrepreneurship, Vol.6(No.13), PP.1-16.

Paul, S., Whittam, G., \& Wyper, J. (2007). The pecking order hypothesis:does it apply to start-up firms? Journal of Small Business and Enterprise Development, Vol.14(No.1), pp. 8-21.

Richard, E. M., \& Mori, N. G. (2012). SMEs Access to Financial Services: Bankers' Eye. Chinese Business Review, Vol.11(No.2), PP.217-223.

Samson, J. a. (2012). A Guide to Quantitative and Qualitative Dissertation Research (Vol. Educational Psychology and Learning Systems Faculty Publications. Paper 1.).

Seyoum, A., Aragie, M., \& Tadesse, D. (n.d.). Growth of Micro and Small Enterprises in Addis Ababa City Administration: A Study on Selected Micro and Small Enterprise in Bole Sub City. International Journal of Scientific and Research Publications, Vol.6(No.1), PP.581-592.

Shahar, W. S., Bahari, N. F., Ahmad, N. W., Rafdi, N. J., \& Fisal, S. (2015). A Review Of Capital Structure Theories: Trade-Off Theory, Pecking Order Theory And Market Timing. Proceeding of the 2 International Conference on Management and Muamalah.

Shyam-Sunder, L., \& Myers, S. C. (1999). Testing static tradeod against pecking order models of capital structure. Journal of Financial Economics, Vol.51, pp. 219-244. 
Singh, S., \& Janor, H. (2013). Determinants of SMEs Financing Pattern in India-A Rotated Factor Analysis Approach. Int. Journal of Economics and Management, Vol.7(No.2), PP.314 - 334.

Stijn, C., \& Tzioumis, K. (2006). Measuring firms' access to finance. Brooking Institution and the World Bank in Washington, D.C.

Tarfasa, S., Ferede, T., Kebede, S., \& Behailu, D. (2016). Determinants of growth of Micro and Small Enterprises : Empirical evidence from Ethiopia.

Tefera, H., Gebremichael, A., \& Abera, N. (2013). Growth Determinants of Micro and Small Enterprises: Evidence from Northern Ethiopia. Journal of Economics and Sustainable Development, Vol.4(No.9), PP.127-134.

Vera, A. M., \& Lopez-Martinez, R. (2010). FEMALE DIRECTORS AND SMES:AN EMPIRICAL ANALYSIS. Journal of Global Strategic Management, Vol.4(No.2), PP.34-46.

Victoria, M., Samuel, B., Lloyd, C., \& Lazarus, M. (2011). Determinants Of Small And Medium Enterprises Failure In Zimbabwe: A Case Study Of Bindura. Vol.2(No.5), PP.82-89.

Waari, D. N., \& Mwangi, W. M. (2015). Factors Influencing Access To Finance By Micro,Small And Medium Enterprises In Meru County, Kenya. International Journal of Economics, Commerce and Management, Vol.3(No.4), PP.1-15.

Wolde, F., \& Geta, E. (2015). Determinants of Growth and Diversification of Micro and Small Enterprises: The Case of Dire Dawa, Ethiopia. Developing Country Studies, Vol.5(No.1), PP.61-75.

Woldeyohanes, H. T. (2014). Dimensions and Determinants of Growth in Micro and Small Enterprises: Empirical Evidence from Mekelle City, Ethiopia. Agris on-line Papers in Economics and Informatics, Vol.6(No.3), PP.104-115.

Yeboah, M. A. (2015). Determinants of SME Growth:An Empirical Perspective Of Smes In The Cape Coast Metropolis,Ghana. Journal of Business in Developing Nations, Vol.14, PP.1-31.

Zarook, T., Rahman, M. M., \& Khanam, R. (2013). The Impact of Demographic Factors on Accessing Finance in Libya's SMEs. International Journal of Business and Management, Vol.8(No.14), PP.55-65.

Zhou, H., \& Wit, G. d. (2009). Determinants and dimensions of firm growth . SCientific AnaLysis of Entrepreneurship, PP.134. 